\title{
Pengaruh Kemampuan Teknik Personal dan Keterlibatan Pemakai pada Efektivitas Penggunaan SIA dengan Pelatihan sebagai Variabel Pemoderasi
}

\author{
Ivana Elvaretta Indrianto ${ }^{1}$ \\ Fakultas Ekonomi dan Bisnis \\ Universitas Udayana, Indonesia
}

\author{
I Dewa Gde Dharma Suputra ${ }^{2}$ \\ Fakultas Ekonomi dan Bisnis \\ Universitas Udayana, Indonesia
}

\begin{abstract}
Surel : ivanaelvaretta@gmail.com
ABSTRAK

Penelitian ini dilakukan untuk memperoleh bukti empiris mengenai pengaruh kemampuan teknik personal dan keterlibatan pemakai pada efektivitas penggunaan SIA dengan pelatihan sebagai pemoderasi di KSU di Kota Denpasar Barat. Penelitian ini dilakukan di 24 KSU di Kota Denpasar Barat. Sampel penelitian ini sebanyak 72 responden dengan metode penentuan sampel purposive sampling. Pengumpulan data dilakukan dengan cara penyebaran kuisioner. Teknik analisis yang digunakan adalah regresi linier berganda. Hasil penelitian ini menunjukkan bahwa kemampuan teknik personal berpengaruh positif signifikan terhadap efektivitas penggunaan SIA. Keterlibatan pemakai berpengaruh positif signifikan terhadap efektivitas penggunaan SIA. Pelatihan memperkuat pengaruh kemampuan teknik personal dan keterlibatan pemakai pada efektifitas penggunaan SIA.
\end{abstract}

Kata Kunci: Kemampuan Teknik Personal; Keterlibatan Pemakai; Efektivitas Penggunaan SIA.

\section{Effect of Personal Engineering Capabilities and User Engagement on the Effectiveness of Using SIA with Training as a Moderating Variable}

\begin{abstract}
This study was conducted to obtain empirical evidence about the influence of personal technical ability and user involvement on the effectiveness of using SIA with training as a moderator at the KSU in West Denpasar City. This research was conducted at 24 KSU in West Denpasar City. The sample of this study were 72 respondents with a purposive sampling method. Data collection is done by distributing questionnaires. The analysis technique used is multiple linear regression. The results of this study indicate that the ability of personal techniques has a significant positive effect on the effectiveness of the use of SIA. User involvement significantly positive effect on the effectiveness of the use of SIA. Training strengthens the influence of personal technical abilities and user involvement on the effective use of SIA.

Keywords: Personal Technical Ability; User Involvement; Effectiveness of SIA Use.
\end{abstract}

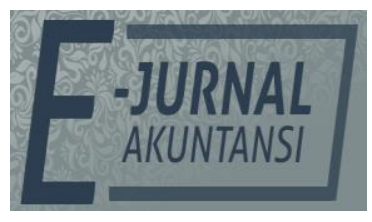

e-ISSN 2302-8556

Vol. 30 No. 8

Denpasar, Agustus 2020 Hal. 2053-2064

DOI:

10.24843/EJA.2020.v30.i08.p12

PENGUTIPAN:

Indrianto, I. E. \& Suputra, I

D. G. D. (2020). Pengaruh Kemampuan Teknik

Personal dan Keterlibatan

Pemakai pada Efektivitas

Penggunaan SIA dengan

Pelatihan sebagai Variabel

Pemoderasi. E-Jurnal

Akuntansi, 30(8), 2053-2064

RIWAYAT ARTIKEL:

Artikel Masuk:

25 Mei 2020

Artikel Diterima: 15 Agustus 2020

Artikel dapat diakses : https://ojs.unud.ac.id/index.php/Akuntansi/index 


\section{PENDAHULUAN}

Perkembangan teknologi informasi berlangsung sangat pesat pada saat ini. dengan adanya perkembangan tekonologi informasi ini berdampak ke peningkatan penggunaan teknologi komputer. Kelton, et al., (2010) menyatakan bahwa perkembangan teknologi informasi mempunyai dampak yang positif dan signifikan bagi perusahaan. Sumber daya pendukung seperti komputer sangat perlu di manfaatkan untuk mendukung perkembangan sistem informasi pada perusahaan atau lembaga sekarang ini. Komputer mampu memproses data lebih efektif dari pada manusia. Komputer tidak hanya dapat melakukan perhitunganperhitungan dengan kecepatan kilat, tetapi juga merupakan prosesor yang sangat akurat dan ekspansif (Adisanjaya, et al., 2017).

Hal yang penting dalam memenangkan persaingan bisnis adalah informasi, terutama informasi keuangan suatu organisasi (Nabizadeh \& Omrani, 2014). Informasi adalah data yang telah diolah yang sudah memiliki makna sehingga bermanfaat untuk mendukung pengambilan keputusan yang efektif. Dalam pengambilan keputusannya, suatu organisasi membutuhkan informasi yang berkualitas. Informasi yang berkualitas dapat dihasilkan dengan adanya Sistem Informasi Akuntansi (SIA).

Sistem Informasi Akuntansi (SIA) adalah komponen-komponen yang saling berhubungan yang terintegrasi untuk mengumpulkan, menyimpan, dan menyebarkan data untuk tujuan perecanaan, pengendalian, koordinasi, analisis dan pengambilan keputusan (Soudani, 2012). Pentingnya penggunaan SIA dalam menghasilkan informasi yang berkualitas dan mendukung proses pengambilan keputusan dapat meningkatkan efisiensi organisasi (Nabizadeh \& Omrani, 2014).

Organisasi perlu menghasilkan informasi yang berkualitas, oleh karena itu SIA yang efektif sangat penting untuk diperhatikan. Efektivitas adalah suatu ukuran yang memberikan gambaran seberapa jauh target dapat dicapai, baik secara kualitas maupun waktu, orientasinya adalah pada keluaran (output) yang dihasilkan (Yamit, 2003). Efektivitas SIA merupakan satu faktor yang signifikan dari keberhasilan manajemen dalam mencapai tujuan organisasi dan pengguna SIA memiliki peran besar dalam efektivitas sistem (Dehghanzade, et al ., 2011).

Turnip \& Suardikha (2018) menyatakan apabila informasi yang di dapat buruk mungkin akan berdampak buruk juga pada pengambilan keputusan. Instansi dapat bergerak maju dalam pekerjaan mereka dengan menerima dukungan yang diperlukan untuk mencapai tujuan yang diminta. Akuntansi merupakan alat dalam mengelola data akuntansi dan keuangan, maka diperlukan suatu sistem informasi untuk menyampaikan informasi tersebut kepada pihak yang membutuhkan yaitu dengan SIA. Perusahaan yang menggunakan SIA terkomputerisasi, kemampuan pengoperasian sistem seorang pengguna sangat dibutuhkan. Pengguna yang mahir dan memahami sistem akan berpengaruh pada kinerja yang dihasilkan sistem tersebut.

Kemampuan teknik personal dapat diartikan sebagai kemampuan seseorang dalam mengoperasikan sistem dalam mengolah data menjadi sebuah informasi yang tepat, akurat, berkualitas serta dapat dipercaya bagi pengguna. Ives, et al., (1983) menyatakan kemampuan teknik personal sistem informasi sebagai rata-rata pendidikan atau tingkat pengalaman dari pengguna. Kemampuan teknik personal pemakai sistem informasi berperan penting dalam 
pengembanga sistem informasi untuk dapat menghasilkan informasi guna menciptakan laporan perencanaan yang akurat. Gustiyan (2014) menyatakan bahwa kemampuan teknik pemakai yang baik akan mendorong pemakai untuk menggunakan SIA sehingga kinerja SIA lebih tinggi.

Irma (2014) menyatakan bahwa keberhasilan penggunaan teknologi informasi didukung oleh peran manusia selaku pengguna dari SIA tersebut. Menurut Rusmiati (2012) keterlibatan pemakai adalah keterlibatan mental dan emosional orang-orang dalam situasi kelompok yang mendorong mereka untuk memberikan kontribusi kepada tujuan kelompok. Manusia yang mengoperasikan SIA dalam suatu organisasi maka tingkah laku manusia sangat penting untuk diperhatikan.

Nurhayati \& Rahmaturayandani (2015) menyatakan untuk meningkatkan efektivitas dari perubahan SIA, maka perlu diberikan edukasi dan pelatihan kepada para perancang dan pengguna sistem sehingga penerapan sistem dapat dilaksanakan sesuai dengan harapan. Pengadaan pelatihan diharapkan dapat membuat pengguna sistem menggunakan kemampuannya untuk mengidentifikasi kebutuhan dari suatu sistem dan dapat mengidentifikasi kekuatan dan kelemahan suatu sistem. Pengetahuan dan kemampuan yang memadai diperoleh dari pelatihan yang berdampak pada peningkatan kemampuan teknik personal dalam menggunakan sistem dan menyelesaikan pekerjaannya (Perbarini, 2012). Pelatihan untuk pengguna sistem diperlukan agar dapat meningkatkan kemampuan karyawan sehingga akan membantu pekerjaannya yang akan berdampak pada tercapainya visi dan misi organisasi.

Pada penelitian ini ingin menguji kembali pengaruh variable kemampuan teknik personal dan keterlibatan pemakai terhadap efektivitas penggunaan SIA. Pada penelitian terdahulu mengenai pengaruh kemampuan teknik personal terhadap efektivitas penggunaan SIA terjadi tidakkonsistenan hasil penelitian mengenai pengaruh tersebut. Penelitian Suryawarman (2013), Wilayanti \& Dharmadiaksa (2015), \& Adisanjaya, et al., (2017) menyatakan bahwa kemampuan teknik personal berpengaruh positif pada efektivitas SIA. Berbeda dengan hasil penelitian dari Galang (2014) \& Mentari (2014) dalam Turnip \& Suardikha (2018) menyatakan bahwa kemampuan teknik personal tidak berpengaruh terhadap kinerja SIA. Tjhai ( 2002), Komara (2005), Perbarini (2012), Surya (2016) menyatakan bahwa keterlibatan pemakai berpengaruh positif dan signifikan pada efektivitas SIA. Hasil yang berbeda diperoleh oleh Daryani (2013) yang menyatakan bahwa keterlibatan pemakai tidak berpengaruh pada efektivitas SIA. Karena terjadi tidakkonsistenan hasil dari penelitian sebelumnya, peneliti menduga ada variabel lain yang ikut mempengaruhi pengaruh kemampuan teknik personal dan keterlibatan pemakai pada efektivitas penggunaan SIA, maka dimasukkan pelatihan sebagai variabel pemoderasi.

Kemampuan teknik personal merupakan salah satu faktor yang mempengaruhi kinerja SIA. Secara umum kemampuan teknik personal sangat dibutuhkan, dimana kemampuan teknik personal akan menunjukkan sejauh mana kualitas pribadi seseorang dalam mengoperasikan sebuah sistem akuntansi. Technology Acceptance Model (TAM) menjelaskan bahwa terdapat dua faktor yang mempengaruhi sikap individu untuk menerima dan menggunakan teknologi, yaitu manfaat dan kemudahan. Teori tersebut menunjukkan bahwa semakin 
mengertinya personal atas manfaat yang diberikan penggunaan SIA maka personal akan menerima dan menggunakan SIA tersebut.

Hal ini juga didukung dengan penelitian yang dilakukan Prabowo, et al., (2013), Wilayanti \& Dharmadiaksa (2016), Adisanjaya, et al., (2017) yang memperoleh hasil bahwa kemampuan personal berpengaruh positif dan signifikan terhadap efektivitas sistem informasi. Kemampuan teknik personal disini berkaitan dengan kemampuan yang dimiliki oleh pemakai SIA, sehingga semakin tinggi kemampuan personal seseorang maka akan meningkatkan efektivitas SIA yang ada. Setiap karyawan harus dapat menguasai penggunaan sistem berbasis komputer agar dapat memperoleh sejumlah transaksi dengan cepat dan terintegrasi, dapat menyimpan data dan mengambil data dalam jumlah yang besar, dapat mengurang kesalahan matematik, menghasilkan laporan tepat waktu dalam berbagai bentuk serta dapat menjadi alat bantu keputusan Dewi \& Dharmadiaksa (2017). Berdasarkan uraian, maka hipotesis dapat dirumuskan sebagai berikut.

$\mathrm{H}_{1}$ : Kemampuan teknik personal berpengaruh positif pada efektivitas pengggunaan sistem informasi akuntansi.

Dalam teori TAM menggambarkan manfaat sistem informasi bagi pemakainya yang berkaitan dengan produktivitas, kinerja tugas, dan efektivitas untuk tujuan yang sesuai dengan keinginan pemakai. Faktor kemanfaatan (usefulness) dan kemudahan pengguna (ease of use) berkaitan dengan keterlibatan pemakai sistem informasi. Ketika individu terlibat dalam penggunaan sistem informasi, maka individu dapat menilai apakah sistem informasi tersebut membuat pemakaian sistem informasi lebih efektif. Menurut Rusmiati (2012) keterlibatan pemakai adalah keterlibatan mental dan emosional orang-orang dalam situasi kelompok yang mendorong mereka untuk memberikan kontribusi kepada tujuan kelompok. Hajiha \& Azizi (2011) menyatakan pengembangan sistem informasi akuntansi adalah faktor efektif yang berpengaruh terhadap kinerja sistem informasi akuntansi.

Menurut Komara (2005) pengaruh keterlibatan pemakai dalam pengembangan sistem berpengaruh positif dan signifikan terhadap efektivitas SIA. Tjhai (2002) berpendapat bahwa keterlibatan pemakai yang semakin sering akan meningkatkan efektivitas SIA dikarenakan adanya hubungan yang positif antara keterlibatan pemakai dalam proses pengembangan sistem informasi dalam SIA. Dengan demikian, hipotesis yang dapat dirumuskan sebagai berikut.

$\mathrm{H}_{2}$ : Keterlibatan pemakai berpengaruh positif pada efektivitas penggunaan sistem informasi akuntansi.

Dalam teori TAM menjelaskan bahwa terdapat dua faktor yag memengaruhi perilaku personal untuk menerima dan menggunakan tekonologi. Dua faktor tersebut adalah kemanfaatan (usefulness) dan kemudahan pengguna (ease of use) (Surendran, 2012). Kemanfaatan (usefulness) ini didefinisikan sebagai tingkat keyakinan individu bahwa pengguna sistem informasi tertentu akan meningkatkan kinerjanya. Dengan adanya pelatihan terhadap pengguna SIA diyakini dapat membuat kemampuan teknik personal individu semakin meningkat sehingga penggunaan SIA menjadi efektif.

Suryawarman (2013) menyatakan bahwa kemampuan teknik personal adalah kemampuan yang dimiliki seseorang yang diperoleh dari pengalaman dan 
dari pelatihan dan pendidikan yang pernah diikuti sehingga dapat meningkatkan kepuasannya untuk menggunakan SIA yang diterapkan oleh suatu organisasi. Kemampuan pemakai dalam mengoperasikan sistem informasi yang diterapkan sangat dibutuhkan. Pelatihan diperlukan agar dapat meningkatkan kemampuan teknik personal pengguna SIA. Berdasarkan uraian, maka hipotesis dapat dirumuskan sebagai berikut.

$\mathrm{H}_{3}$ : Pelatihan mempengaruhi pengaruh kemampuan teknik personal pada efektivitas penggunaan SIA.

Dalam teori TAM, selain faktor kemanfaatan (usefulness) adalah faktor kemudahan penggunaan (ease of use). Kemudahan penggunaan dapat didefinisikan sebagai tingkat dimana seseorang meyakini bahwa penggunaan sistem informasi merupakan hal yang mudah dan tidak memerlukan usaha keras dari pemakainya. Konsep ini mencakup kejelasan tujuan penggunaan sistem informasi dan kemudahaan penggunaan sistem untuk tujuan sesuai dengan keinginan pemakai (Davis, 1989). Keterlibatan pemakai sistem informasi akuntansi sangat bergantung dengan bagaimana sistem tersebut digunakan. Kemudahan penggunaan dapat membuat pemakai lebih efektif dalam menggunakan sistem informasi. Mengadakan pelatihan pada pemakai yang terlibat dalam sistem informasi akuntansi dapat membuat penggunaan sistem informasi akuntansi menjadi lebih efektif.

Baroudi, et al., (1986) berpendapat bahwa keterlibatan pemakai dalam pengembangan sistem memberikan kepastian secara langsung baik kepuasan pemakai maupun penggunaan sistem. Tjhai (2002) berpendapat bahwa kinerja SIA akan lebih tinggi apabila program pelatihan pemakai diperkenalkan. Hal tersebut di perkuat oleh pernyataan Amrul, Sadat, \& Syar'ie (2005) yang menyebutkan, pelatihan merupakan sesuatu yang terpenting guna memberikan latar belakang yang bertujuan mendekatkan pemakai dengan penggunaan teknik komputer secara umum sebagai bagian dari proses penggunaan sistem yang spesifik. Berasarkan uraian, maka hipotesis dapat dirumuskan sebagai.

$\mathrm{H}_{4}$ : Pelatihan mempengaruhi pengaruh keterlibatan pemakai pada efektivitas penggunaan SIA.

\section{METODE PENELITIAN}

Penelitian ini dilakukan pada KSU di Kota Denpasar Barat. Perkembangan lembaga keuangan yang pesat pesat memicu persaingan ketat antara KSU dengan lembaga keuangan lainnya, untuk itu diperlukan sistem informasi akuntansi untuk meningkatkan kinerja KSU sehingga dapat bersaing dengan lembaga keuangan lainnya. Objek dalam penelitian ini adalah efektivitas penggunaan SIA yang dipengaruhi kemampuan teknik personal dan keterlibatan pemakai dengan pendidikan dan pelatihan sebagai variabel pemoderasi pada Koperasi Serba Usaha di Kota Denpasar Barat.

Populasi dalam penelitian ini adalah seluruh karyawan KSU yang berada di Kota Denpasar Barat sebanyak 251 karyawan. Sampel penelitian yang berbentuk responden dalam penelitian ini adalah ketua, manajer, kasir/admin dan karyawan di KSU yang sudah mempergunakan SIA berbasis komputer secara langsung, karena responden tersebut yang lebih berkompeten dan mengetahui penerapan SIA berbasis komputer di KSU tersebut. Sehingga hasil yang diperoleh 
dari responden terlihat layak untuk digunakan. Total sampel yang memenuhi kriteria dalam penelitian ini adalah 72 orang.

Teknik analisis data yang dipergunakan untuk pemecahan masalah dalam penelitian ini adalah teknik analisis regresi linear berganda. Suliyanto (2011) menyatakan bahwa model regresi linear berganda ditunjukkan oleh persamaan sebagai berikut.

$$
Y=\alpha+\beta_{1} x_{1}+\beta_{2} x_{2}+\beta_{3} x_{3}+\varepsilon
$$

Keterangan :

Y : Efektivitas Penggunaan Sistem Informasi Akuntansi

$\alpha$ : Konstanta

$\beta_{1}, \beta_{2}, \beta_{3}$ : Koefisien regresi variabel independen

$\mathrm{x}_{1}$ : Kemampuan Teknik Personal

$\mathrm{x}_{2}$ : Keterlibatan Pemakai

$\mathrm{x}_{3}$ : Pendidikan dan Pelatihan

$\varepsilon$ : Nilai residu

\section{HASIL DAN PEMBAHASAN}

Statistik deskriptif dalam penelitian ini disajikan untuk memberikan informasi tentang karakteristik variabel penelitian. Nilai minimum menunjukkan nilai terkecil/terendah pada suatu gugus data. Nilai maksimum menunjukkan nilai terbesar/tertinggi pada suatu gugus data. Rata-rata (mean) merupakan cara yang paling umum digunakan untuk mengukur nilai sentral dari suatu distribusi dara yang diteliti. Deviasi standar adalah ukuran yang menunjukkan standar penyimpangan data observasu terhadap rata-rata datanya. Adapu hasil statistik deskriptif pada penelitian ini yang dapat dilihat pada Tabel 1, sebagai berikut.

Tabel 1. Statistik Deskriptif

\begin{tabular}{llllll}
\hline & $\mathrm{N}$ & Minimum & Maximum & Mean & Std. Deviation \\
\hline $\begin{array}{l}\text { Efektivitas Penggunaan } \\
\text { SIA }\end{array}$ & 72 & 22.00 & 33.00 & 29.0278 & 3.00222 \\
$\begin{array}{l}\text { Kemampuan Teknik } \\
\text { Personal }\end{array}$ & 72 & 22.00 & 39.00 & 32.0139 & 3.22618 \\
$\begin{array}{l}\text { Keterlibatan Pemakai } \\
\text { Pelatihan }\end{array}$ & 72 & 14.00 & 25.00 & 19.9028 & 2.69146 \\
\hline
\end{tabular}

Sumber: Data Penelitian, 2020

Berdasarkan Tabel 1, dapat disimpulkan bahwa jumlah pengamatan penelitian berjumlah 72. Variabel efektivitas penggunaan SIA memiliki nilai minimum sebesar 22 dan nilai maksimum sebesar 33 dengan nilai rata-rata sebesar 29,0278 . Standar deviasi pada variabel efektivitas penggunaan SIA adalah sebesar 3,00222 hal ini menunjukkan bahwa standar penyimpangan data pada nilai rataratanya adalah 3,00222.

Variabel kemampuan teknik personal memiliki nilai minimum sebesar 22 dan nilai maksimum sebesar 39 dengan nilai rata-rata sebesar 32,0139. Standar deviasi pada variabel efektivitas penggunaan SIA adalah sebesar 3,22618 hal ini menunjukkan bahwa standar penyimpangan data pada nilai rata-ratanya adalah 3,22618 .

Variabel keterlibatan pemakai memiliki nilai minimum sebesar 14 dan nilai maksimum sebesar 25 dengan nilai rata-rata sebesar 19,9028. Standar deviasi pada 
variabel efektivitas penggunaan SIA adalah sebesar 2,69146 hal ini menunjukkan bahwa standar penyimpangan data pada nilai rata-ratanya adalah 2,69146.

Variabel pelatihan memiliki nilai minimum sebesar 15 dan nilai maksimum sebesar 25 dengan nilai rata-rata sebesar 20,6528. Standar deviasi pada variabel efektivitas penggunaan SIA adalah sebesar 2,18290 hal ini menunjukkan bahwa standar penyimpangan data pada nilai rata-ratanya adalah 2,18290.

Pengujian data dalam penelitian ini menggunakan teknik analisis regresi moderasi. Perhitungan koefisien regresi moderasi dilakukan dengan analisis regresi melalui software SPSS 24.0 for Windows, diperoleh hasil yang ditunjukan pada Tabel 2.

Tabel 2. Hasil Analisis Regresi Moderasi

\begin{tabular}{llllll}
\hline Model & \multicolumn{2}{l}{$\begin{array}{l}\text { Unstandardized } \\
\text { Coefficients }\end{array}$} & \multicolumn{2}{l}{$\begin{array}{l}\text { Standardized } \\
\text { Coefficients }\end{array}$} \\
& $\mathrm{B}$ & Std. Error & Beta & $t$ & Sig. \\
\hline 1 (Constant) & -3.145 & 4.061 & & -.774 & .441 \\
Kemampuan & Teknik & & & & \\
Personal & .330 & .114 & .355 & 2.893 & .005 \\
Keterlibatan Pemakai & .283 & .089 & .254 & 3.201 & .002 \\
Pelatihan & .085 & .152 & .062 & .556 & .580 \\
X1.X3 & .017 & .006 & .354 & 2.748 & .008 \\
X2.X3 & .013 & .005 & .262 & 2.552 & .013 \\
\hline
\end{tabular}

Sumber: Data Penelitian, 2020

Berdasarkan hasil analisis regresi linier berganda seperti yang disajikan pada Tabel 2, maka persamaan strukturalnya adalah sebagai berikut:

$$
Y=-3,145+0,330 X_{1}+0,283 X_{2}+0,085 X_{3}+0,017 X_{1} X_{3}+0,013 X_{2} X_{3}
$$

Tabel 2 menunjukkan bahwa variabel kemampuan teknik personal, keterlibatan pemakai, interaksi X1.X3 dan interaksi X2.X3 memiliki nilai signifikansi kurang dari 0,05 , hal ini berarti bahwa variabel tersebut memiliki pengaruh yang signifikan pada variabel efektivitas penggunaan SIA.

Koefisien determinasi $\left(R^{2}\right)$ digunakan untuk mengetahui dan mengukur kemampuan model dalam menerangkan variasi variabel independen. Peneliti menggunakan nilai adjusted $\mathrm{R}^{2}$ pada saat mengevaluasi yang mana model regresi terbaik, karena tidak seperti $\mathrm{R}^{2}$, nilai adjusted $\mathrm{R}^{2}$ dapat naik atau turun apabila satu variabel independen ditambahkan ke dalam model. Hasil uji koefisien determinasi dapat dilihat dalam table 3.

Tabel 3. Hasil Uji Koefisien Determinasi

\begin{tabular}{cllll}
\hline Model & $R$ & $R$ Square & Adjusted R Square & Std. Error of the Estimate \\
\hline $1.776^{\mathrm{a}}$ & .603 & .572 & 1.96313 \\
\hline
\end{tabular}

Sumber: Data Penelitian, 2020

Hasil uji memberikan hasil dimana diperoleh besarnya adjusted $\mathrm{R}^{2}$ (koefisien determinasi yang telah disesuaikan) pada Tabel 4.9 adalah 0,572. Ini berarti variasi efektivitas penggunaan SIA dapat dipengaruhi secara signifikan oleh variabel kemampuan teknik personal $\left(X_{1}\right)$, keterlibatan pemakai $\left(X_{2}\right)$, pelatihan (X3), interaksi X1.X3 dan interaksi X2.X3 sebesar 57,2 persen, sedangkan sisanya sebesar 42,8 persen dijelaskan oleh faktor-faktor lain yang tidak dijelaskan dalam model penelitian. 
Uji keterandalan model atau uji kelayakan model atau yang lebih populer disebut sebagai uji $\mathrm{F}$ merupakan tahapan awal mengidentifikasi model regresi yang diestimasi layak atau tidak. Layak (andal) disini maksudnya adalah model yang diestimasi layak digunakan untuk menjelaskan pengaruh variabel-variabel bebas terhadap variabel terikat. Sig. Tabel ANOVA menunjukkan besarnya angka probabilitas atau signifikansi pada perhitungan ANOVA. Nilai yang tertera digunakan untuk uji kelayanan Model Analisis (dimana sejumlah variabel $x$ mempengaruhi variabel y) dengan ketentuan angka probabilitas yang baik untuk digunakan sebagai model regresi harus $<0,05$. Nilai ini bisa dilihat pada kolom Sig. Jika signifikansi < 0,05, maka Model Analisis dianggap layak. Jika nilai signifikansi $>0,05$, maka Model Analisis dianggap tidak layak. Hasil uji F dalam penelitian ini dapat dilihat pada Tabel 4.

Tabel 4. Hasil Uji F

\begin{tabular}{lllllll}
\hline Model & & Sum of Squares & $d f$ & Mean Square & $F$ & Sig. \\
\hline 1 & Regression & 385.589 & 5 & 77.118 & 20.010 & $.000^{\mathrm{b}}$ \\
& Residual & 254.356 & 66 & 3.854 & & \\
& Total & 639.944 & 71 & & & \\
\hline
\end{tabular}

Sumber: Data Penelitian, 2020

Hasil uji F (Ftest) menunjukkan bahwa nilai signifikansi P value 0,000 yang lebih kecil dari $a=0,05$, ini berarti model yang digunakan pada penelitian ini adalah layak. Hasil ini memberikan makna bahwa seluruh variabel independen yaitu kemampuan teknik personal $\left(\mathrm{X}_{1}\right)$, keterlibatan pemakai $\left(\mathrm{X}_{2}\right)$, pelatihan $\left(\mathrm{X}_{3}\right)$, variabel interaksi antara kemampuan teknik personal dengan pelatihan (X1.X3) dan variabel interaksi antara keterlibatan pemakai dengan pelatihan (X2.X3) mampu memprediksi atau menjelaskan fenomena efektivitas penggunaan SIA. Hal ini berarti model dapat digunakan untuk analisa lebih lanjut atau dengan kata lain model dapat digunakan untuk memproyeksikan karena hasil goodness of fitnya baik dengan nilai signifikansi $\mathrm{P}$ value 0,000 .

Berdasarkan hasil analisis pengaruh kemampuan teknik personal pada efektivitas penggunaan SIA diperoleh nilai signifikasi sebesar 0,005 dengan kefisien regresi positif sebesar 0,330. Nilai Signifikasi 0,005 < 0,05 mengindikasikan bahwa $\mathrm{H}_{1}$ diterima. Hasil ini mempunyai arti bahwa Kemampuan teknik personal berpengaruh positif dan signifikan terhadap efektivitas penggunaan SIA. Hal ini berarti bahwa semakin renda tingkat kemampuan teknik personal maka tingkat efektivitas penggunaan SIA akan semakin rendah, begitu pula sebaliknya apabila karyawan memiliki kemampuan teknik personal yang tinggi maka efektivitas penggunaan SIA akan semakin tinggi. Hal tersebut sesuai dengan teori TAM yang menunjukkan bahwa semakin mengerti personal atas manfaat yang diberikan penggunaan SIA maka personal akan menerima dan menggunakan SIA tersebut. Kemampuan teknik personal disini berkaitan dengan kemampuan yang dimiliki pemakai SIA, sehingga semakin tinggi kemampuan personal seseorang maka akan meningkatkan efektivitas penggunaan SIA yang ada. Setiap karyawan harus dapat menguasai penggunaan sistem berbasis komputer agar dapat memperoleh jumlah transaksi dengan cepat dan terintegrasi, dapat menyimpan data dan mengambil data dalam jumlah yang besar, dapat mengurang kesalahan matematik, menghasilkan laporan tepat waktu dalam berbagai bentuk serta dapat menjadi alat bantu keputusan Dewi \& Dharmadiaksa (2017). Hasil artikel ini sejalan 
dengan hasil artikel yang dilakukan oleh Prabowo, et al., (2013), Wilayanti \& Dharmadiaksa (2016), Adisanjaya, et al., (2017) yang menyatakan bahwa kemampuan teknik personal berpengaruh positif dan signifikan terhadap efektivitas penggunaan SIA.

Hasil analisis pengaruh keterlibatan pemakai terhadap efektivitas penggunaan SIA diperoleh nilai signifikansi sebesar 0,002 dengan nilai koefisien regresi positif sebesar 0,283. Nilai Signifikansi 0,002 <0,05 mengindikasi bahwa $\mathrm{H}_{2}$ diterima. Hasil ini mempunyai arti bahwa keterlibatan pemakai berpengaruh positif dan signifikan terhadap efektivitas penggunaan SIA. Ketika individu terlibat dalam penggunaan sistem informasi, maka indiviu dapat menilai apakah sistem informasi tersebut membuat pemakaian sistem informasi lebih efektif. Dalam teori TAM menggambarkan manfaat sistem informasi bagi pemakainya yang berkaitan dengan produktivitas, kinerja tugas, dan efektivitas untuk tujuan yang sesuai dengan keinginan pemakai. Faktor kemanfaatan (usefulness) dan kemudahan pengguna (ease of use) berkaitan dengan keterlibatan pemakai sistem informasi. Hasil ini didukung oleh penelitian Tjhai (2002) \& Komara (2005) yang menyatakan bahwa keterlibatan pemakai dalam pengembangan sistem berpengaruh positif dan signifikan terhadap efektivitas penggunaan SIA.

Variabel moderasi dapat diklasifikasikan menjadi 4 jenis. Masing-masing klasifikasi moderasi dapat diidentifikasi sebagaimana contoh berikut, jika $X$ adalah variabel predictor, $\mathrm{Y}$ variabel terikat dan $\mathrm{M}$ variabel moderasi maka persamaan regresi yang dapat dibentuk sebagai berikut.

$$
Y=\beta_{1} X_{1}+\beta_{2} X_{2}+\beta_{3} X_{3}+\beta_{4} X_{1} * X_{3}
$$

Berdasarkan hasil analisis pengaruh kemampuan teknik personal pada efektivitas penggunaan SIA dengan pelatihan sebagai variabel moderasi diperoleh nilai signifikansi sebesar 0,005 dengan nilai koefisien regresi sebesar 0,330 . Nilai Signifikansi variabel moderasi $\left(\beta_{3}\right)$ Pelatihan sebesar 0,580 (non significant) dan nilai signifikan variabel Interaksi antara Kemampuan teknik personal dan Pelatihan $\left(\beta_{4}\right)$ signifikan sebesar 0,008, hal ini mengindikasikan variabel moderasi merupakan tipe moderasi murni (pure moderasi). Pure moderasi merupakan variabel yang memoderasi hubungan antara variabel prediktor dan variabel tergantung di mana variabel moderasi murni berinteraksi dengan variabel prediktor tanpa menjadi variabel prediktor. Hal ini menunjukkan bahwa pelatihan memperkuat pengaruh kemampuan teknik personal pada efektivitas penggunaan SIA. Dalam teori TAM terdapat faktor kemanfaatan (usefulness) ini didefinisikan sebagai tingkat keyakinan individu bahwa penggunaan sistem informasi tertentu akan meningkatkan kinerjanya. Dengan adanya pelatihan terhadap penggunaan SIA diyakini dapat membuat kemampuan teknik personal individu semakin meningkat sehingga penggunaan SIA menjadi efektif. Hasil ini sejalan dengan penelitian Suryawarman (2013) yang menyatakan bahwa pelatihan memperkuat hubungan antara pengaruh kemampuan teknik personal pada efektivitas penggunaan SIA.

Berdasarkan hasil analisis pengaruh Keterlibatan pemakai pada Efektivitas penggunaan SIA dengan Pelatihan sebagai Variabel Moderasi diperoleh nilai signifikansi sebesar 0,002 dengan nilai koefisien regresi sebesar 0,283. Nilai Signifikansi variabel moderasi $\left(\beta_{3}\right)$ Pelatihan sebesar 0,580 (non significant) dan nilai signifikan variabel Interaksi antara Keterlibatan pemakai dan Pelatihan $\left(\beta_{5}\right)$ 
signifikan sebesar 0,013 hal ini mengindikasikan variabel moderasi merupakan tipe moderasi murni (pure moderasi). Pure moderasi merupakan variabel yang memoderasi hubungan antara variabel prediktor dan variabel tergantung di mana variabel moderasi murni berinteraksi dengan variabel prediktor tanpa menjadi variabel prediktor. Hal ini menunjukkan bahwa pelatihan memperkuat pengaruh keterlibatan pemakai pada efektivitas penggunaan SIA. Faktor kemudahan pengguna (ease of use) dalam teori TAM dapat didefinisikan sebagai tingkat dimana seseorang meyakini bahwa penggunaan sistem informasi merupakan hal yang mudah dan tidak memerlukan usaha keras dalam pemakaiannya. Keterlibatan pemakai sistem informasi sangat bergantung dengan bagaimana sistem tersebut digunakan. Mengadakan pelatihan pada pemakai yang terlibat dalam SIA dapat membuat penggunaan SIA menjadi lebih efektif. Hal ini sejalan dengan penelitian Baroudi, et al., (1986) \& Tjhai (2002) yang menyatakan bahwa pelatihan memperkuat hubungan antara keterlibatan pemakai pada efektivitas penggunaan SIA.

Hasil analisis regresi moderasi menunjukkan bahwa nilai koefisien regresi Keterlibatan pemakai $\left(\beta_{2}\right)$ positif signifikan dan $\beta_{5}$ positif signifikan, maka variabel Pelatihan merupakan variabel moderating yang memperkuat pengaruh Keterlibatan pemakai pada efektivitas penggunaan SIA

Hasil penelitian ini diharapkan dapat memberikan tambahan informasi mengenai pengaruh kemampuan teknik personal dan keterlibatan pemakai pada efektivitas penggunaan SIA dengan pelatihan sebagai variabel moderasi. Terdapat bukti empiris bagi peneliti dalam pengaruh kemampuan teknik personal dan keterlibatan pemakai yang berhubungan dengan efektivitas penggunaan SIA dengan dimoderasi oleh pelatihan. Hal ini membuktikan bahwa karyawan membutuhkan pelatihan yang dapat meningkatkan kemampuan teknik personal dan keterlibatan pemakai agar dapat menggunakan SIA secara efektif.

\section{SIMPULAN}

Kemampuan teknik personal berpengaruh positif dan signifikan pada efektivitas penggunaan SIA. Hal ini memberi gambaran bahwa semakin tinggi kemampuan teknik personal seseorang maka semangkin efektif penggunaan SIA oleh karyawan KSU di Kota Denpasar Barat. Keterlibatan pemakai berpengaruh positif dan signifikan pada efektivitas penggunaan SIA. Berkaitan dengan hal tersebut semakin baik keterlibatan pemakai SIA maka semakin efektif penggunaan SIA oleh karyawan KSU di Kota Denpasar Barat. Pelatihan memperkuat pengaruh kemampuan teknik personal terhadap efektivitas penggunan SIA. Dengan diadakannya pelatihan kepada karyawan maka akan memberikan pengaruh positif terhadap kemampuan teknik personal yang akan membuat efektivitas penggunaan SIA semakin baik di KSU di Kota Denpasar Barat. Pelatihan memperkuat pengaruh keterlibatan pemakai terhadap efektivitas penggunaan SIA. Dengan diadakannya pelatihan maka dapat meningkatkan efektivitas penggunaan SIA.

Hasil penelitian ini dapat menjadi pertimbangan bagi KSU dalam penggunaan SIA. karyawan memerlukan pelatihan lebih lanjut agar dapat mengefektivkan penggunaan SIA dalam menghasilkan laporan keuangan. Dan karyawan dapat meningkatkan kemampuan teknik personal serta keterlibatan 
pemakai agar laporan keuangan yang dihasilkan lebih baik. Peneliti selanjutnya disarankan dapat memperluas ruang lingkup sampel tidak hanya KSU di Kota Denpasar Barat namun juga Koperasi lainnya di Kota Denpasar.

\section{REFERENSI}

Adisanjaya, K., Wahyuni, M. A., \& Purnamawati, I. G. A. (2017). Pengaruh Kemampuan Personal, Pelatihan Dan Pendidikan Serta Pemanfaatan Teknologi Terhadap Efektivitas Sistem Informasi Akuntansi Pada Mini Market Bali Mardana. E-Journal S1 Akuntansi Universitas Pendidikan Ganesha.

Amrul, Sadat, \& Syar'ie, A. (2005). Analisis Beberapa Faktor Yang Berpengaruh Terhadap Proses Pengembangan Kualitas Sistem. (Simposium). Solo.

Baroudi, J., Olson, M., \& Ives, B. (1986). An Empirical Study of The Impact of User Involvement on system Usage and Information Satisfaction Communications of The ACM. 232-238.

Daryani. (2013). Faktor-Faktor Yang Mempengaruhi Kinerja Sistem Informasi Akuntansi (Survei pada Bank Perkreditan Rakyat di Kabupaten Boyolali). Universitas Muhamadiyah Surabaya.

Davis, F. (1989). Perceived Usefulness, Perceived Ease of Use, and Acceptance of Information System Technology. Management Information Systems Quartely, 13(3), 319-339.

Dehghanzade, H., Moradi, M. A., \& Raghibi, M. (2011). A Survey of Human Factors' Impacts on the Effectiveness of Accounting Information Systems. International Journal of Business Administration, 2(4). https:// doi.org/10.5430/ijba.v2n4p166

Dewi, N. L. A. A., \& Dharmadiaksa, I. B. (2017). Pengaruh Efektivitas SIA, Pemanfaatan TI dan Kemampuan Teknis Pemakai SIA Terhadap Kinerja Individu. E-Junal Akuntansi Universitas Udayana, 18(1), 386-414.

Galang, Rahadian Prabowo, A. M. (2014). Faktor-Faktor yang Mempengaruhi Kinerja Sistem Informasi Akuntansi. Accounting Analysis Journal, 3(1), 1-9.

Gustiyan, H. (2014). Analisis faktor-faktor yang mempengaruhi kinerja sistem informasi akuntansi pada bank perkreditan rakyat (BPR) Ditanjungpinang. Lincolin Arsyad, 3(2), 1-46. https:// doi.org/http://dx.doi.org/110.21043/equilibrium.v3i2.1268

Hajiha, Z., \& Azizi, Z. A. P. (2011). Effective Factors on Alignment of Accounting Information Systems in Manufacturing Companies: Evidence from Iran. Journal Information Management and Business Review, 3(3), 158-170.

Irma, D. P. (2014). Pengaruh Kemampuan Teknik Personal, Program Pelatihan dan Pendidikan Pemakai, Insentif dan Partisipasi Manajemen pada Kinerja Penerapan Sistem Informasi Akuntansi.

Ives, B., Olson, M. H., \& Baroudi, J. J. (1983). The measurement of user information satisfaction. Communications of the ACM, 26(10), 785-793. https:/ / doi.org/10.1145/358413.358430

Kelton, Andrea, S., Robin, R. P., \& Brad, M. T. (2010). The Effect of Information Presentation Format on Judgement and Decision Making: A Review of The Information System Research. Journal of Information System, 24 (2), 79-105.

Komara, A. (2005). Analisis Faktor-Faktor yang Mepengaruhi Kinerja Sistem Informasi Akuntansi. Jurnal Ilmiah. Universitas Swadaya Gunung Jati. 
Nabizadeh, S. M., \& Omrani, S. A. (2014). Effective Factors on Accounting Information System Alignment; A Step Towards Organizational Performance Improvement. International Journal of Scientific and Research Publications., 4(9).

Nurhayati, N., \& Rahmaturayandani, E. (2015). Effects of Top Management Support, Education and Training on the Effectiveness of Accounting Information System ( Survey on Government-Owned Insurance Companies in Bandung ). International Journal of Managerial Studies and Research, 3(10), 2349.

Perbarini, Ni Kadek Ayu dan Juliarsa, G. (2012). Analisis Faktor-Faktor Yang Mempengaruhi Kinerja Sistem Informasi Akuntansi Pada LPD Di Kecamatan Denpasar Utara. Fakultas Ekonomi Universitas Udayana.

Prabowo, R. R., Sukirman, \& Hamidi, N. (2013). Faktor-faktor yang mempengaruhi Kinerja Sistem Informasi Akuntansi di Bank Umum Kota $\begin{array}{llll}\text { Surakarta. JUPE UNS, 119-130. } & \text { 2(1), }\end{array}$ https:// doi.org/https:/ / doi.org/10.1017/CBO9781107415324.004

Rusmiati, R. (2012). Pengaruh keterlibatan pengguna, Kapabilitas Personal Sistem Informasi, Ukuran Organisasi, dan Formalisasi pengembangan system terhadap kepuasan pengguna system informasi akuntansi. Universitas Udayana.

Soudani, S. N. (2012). The Usefulness of an Accounting Information System for Effective Organizational Performance. International Journal of Economics and Finance, 4(5), 136-143.

Suliyanto. (2011). Ekonometrika Terapan: Teori Dan Aplikasi Dengan SPSS (1st ed.). Yogyakarta: ANDI.

Surendran, P. (2012). Technology Acceptance Model: a Survey of Literature. International Journal of Business and Social Research (IJBSR), 2(4).

Surya, Anak Agung Made dan Suardikha, I. M. S. (2016). Faktor-Faktor Yang Berpengaruh Pada Kepuasan Pemakai Sistem Informasi Akuntansi Lembaga Perkreditan Desa Di Kecamatan Mengwi. E-Jurnal Akuntansi Universitas Udayana, 15(1), 317-348.

Suryawarman, K. (2013). Faktor-Fator Yang Mempengaruhi Kinerja Sistem Informasi Akuntansi Pada Restoran Waralaba Asing Di Kota Denpasar. Universitas Udayana.

Tjhai, F. J. (2002). Faktor-Faktor yang Mempengaruhi Kinerja Sistem Informasi Akuntansi. Jurnal Bisnis Dan Akuntasi, 4(2), 135-154.

Turnip, T. R. E. br., \& Suardikha, I. M. S. (2018). Pengaruh Kemampuan Teknik Personal, Pelatihan dan Pendidikan terhadap Efektivitas Penggunaan SIA Pada Rumah Sakit. E-Jurnal Akuntansi, 22, 1419-1444. https:// doi.org/10.24843/EJA.2018.v22.i02.p22

Wilayanti, Ni Wayan., dan D. I. . (2015). Pengaruh Keterlibatan dan Kemampuan Teknik Personal pada Efektivitas Penggunaan Sistem Informasi Akuntansi pada LPD di Kecamatan Tegalalang. E-Jurnal Akuntansi Universitas Udayana, 15(2), 1310-1337.

Wilayanti, N., \& Dharmadiaksa, I. (2016). Keterlibatan Dan Kemampuan Teknik Personal Pada Efektivitas Penggunaan Sistem Informasi Akuntansi. E-Jurnal Akuntansi, 15(2), 1310-1337.

Yamit, Z. (2003). Manajemen Produksi dan Operasi (2nd ed.). Yogyakarta: EKONISIA. 